\title{
PREIOTAREA ÎN LIMBA ROMÂNĂ
}

\begin{abstract}
Tomasz Klimkowski, Preiotarea în limba română [Preiotacisation in Romanian], Studia Romanica Posnaniensia, Adam Mickiewicz University Press, Poznań, vol. XLI/2: 2014, pp. 41-57. ISBN 978-83-232-2703-8. ISSN 0137-2475. eISSN 2084-4158. DOI: 10.7169/strop2014.412.004

This paper analyses the phenomenon of preiotacisation in Romanian, which consists in the prothesis of a semi-consonant [j] before the initial [e]. In fact, this is only an orthographic convention, because in most cases (eu, ele, ești, e, este, eram) the initial [je] segment is a proper diphthong of different origins that is written $e$, instead of $i e$, like in other words. Preiotacisation appears only in the pronouns $e l, e i$ and in the Old Romanian pronunciation of some borrowed words. The [j]-prothesis cannot be separated from other types of prothesis attested in the spoken language. This tendency is parallel to the similar phenomenon from Slavic languages and possibly was developed under their influence.
\end{abstract}

Keywords: pronunciation, preiotacisation, prothesis, Romanian

Preiotarea (iodizarea) este definită ca un fenomen fonetic care constă în apariția semiconsoanei [j] înaintea unei vocale aflate la început de cuvânt sau de silabă (Sala, 1989: 252). În cazul limbii române, termenul se folosește mai ales cu privire la vocala inițială [e] în cazul în care aceasta este ortografiată $e$, dar se pronunță, conform ortoepiei actuale, ca [je]. Prin urmare, fenomenul constituie un tip de diftongare, rezultatul preiotării fiind, de fapt, un diftong ascendent. Termenul de preiotare este, totuși, preferabil celui de diftongare (O. Nandriș denumește preiotarea „o falsă diftongare” - Nandriș, 1963: 214), pentru că rezultatul preiotării nu este întotdeauna interpretat ca diftong, mai ales dacă nu se notează în scris. Conform unor lingviști, primul element al segmentului respectiv nu se realizează ca o semiconsoană propriu-zisă: „În $e l$ vocala iniţială are, ca aproape toate $e$ iniţiale, un timbru uşor palatal; ar fi însă o greşeală să fie transcrisă ie, cum face Scriban" (Ciorănescu, 2002: 311). Em. Vasiliu transcrie este ca [ $\left.{ }^{\mathrm{j}} \mathrm{este}\right] \sim$ [este] și iepure ca [jepure] (Vasiliu, 1965: 96, 104). Transcrierea $\left[{ }^{\mathrm{j} e} \mathrm{e}\right.$ ar sugera o realizare intermediară, între [je] cu [j] (semivocalic) și [e] „pur”, dar autorul constată în continuare că ,,apendicele asilabic" $\left.{ }^{\mathrm{j}}\right]$ poate fi identificat cu semivocala [j] (Vasiliu, 1965: 107). În mod normal, segmentele transcrise de Vasiliu ca [ $\left.{ }^{\mathrm{j} e}\right]$ și [je] se pronunță în mod identic, ca [je], lucru confirmat prin analize de laborator: 

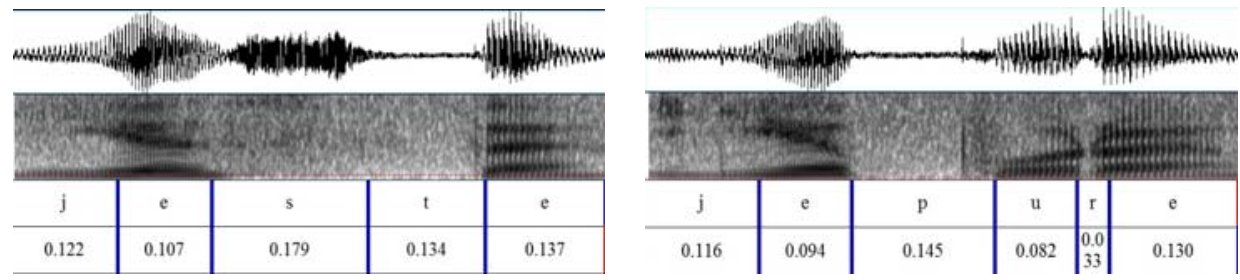

În ceea ce privește cuvintele care în limba standard trebuie pronunțate cu „preiotare”, acest lucru este reglementat de normele Academiei Române. Ultima ediție a îndreptarului ortoepic impune pronunția [e], conform formei scrise, la neologisme, și pronunția [je], la pronumele personale $e u, e l$, ei, ele și formele verbului a fi: ești, este, e, eram, erai, era, erați, erau (Rădulescu, 1995: 12).

Așadar, pronunția preiotată și nepreiotată se orientează, în general, după etimologia cuvintelor: cele noi, fără excepție, nu admit preiotarea, aceasta apărând exclusiv la un număr limitat de cuvinte vechi, adunate în două categorii de ordin morfologic sau semantic (pronume personale - verbul $a$ fi). Li se mai adaugă o formă izolată - adverbul estimp 'în acest an' (Avram, 1990). Criteriul etimologic este, totuși, fals și preiotarea pare a fi, de fapt, mai degrabă o convenție grafică decât un fenomen fonetic. În majoritatea cazurilor în care [je] inițial este notat $e$, din punct de vedere istoric nu este vorba despre preiotare, ci despre o diftongare propriu-zisă. De obicei, nici lingviștii care se ocupă de problema respectivă nu fac această distincție. De exemplu, referindu-se la preiotare, Em. Vasiliu, M. Sala și W. Mańczak ${ }^{1}$ citează, respectiv, formele $e u$, este și era, în care $e$, după cum vom încerca să demonstrăm, nu reprezintă neapărat un [e] preiotat, ci un diftong propriuzis, cel puțin dintr-o perspectivă diacronică. În schimb, Rosetti (1954: 29) exemplifică fenomenul cu forma $\mathrm{el}$ care în mod indubitabil reprezintă o preiotare propriu-zisă. În alte lucrări i se adaugă și forma ești, care însă este mai discutabilă (Sala, 1989: 252; Sala, 2001: 454). În acelaşi timp, cele două categorii de cuvinte preiotate (opuse celor nepreiotate) sunt o creație artificială cu un scop mai degrabă practic, cel de a facilita memorizarea lor și de a evita greșeli de scriere sau pronunție. De fapt, cuvintele respective trebuie clasificate altfel, independent de semantismul lor și în funcție de originea segmentului inițial [je].

1 „Fenomenul preiotării lui $e$ (iel, ieste)” (Sala, 1970: 22); „În meglenoromână apar forme preiotate: [jew, jo, iwa] $e u$ ” (Vasiliu, 1968: 68); „Pod wpływem słowiańskim w wyrazach zaczynających się od $e$ występuje prejotacja, czego nie notuje pisownia, np. w era 'był' < 'erat' pierwsza sylaba wymawiana jest jak pol. je" [,Sub influența slavă, în cuvintele care încep cu $e$, apare o preiotare, lucru care nu este redat în scris, de ex. în era < 'erat', prima silabă se pronunță ca pol. je" - trad. T.K.] (Mańczak, 1988: 632). 


\section{ORIGINEA DIFTONGULUI [JE] INIȚIAL DIN ROMÂNĂ}

În evoluția fonetică de la latină la romanica balcanică, cele zece vocale inițiale, prin pierderea cantității vocalice și contopirea unor vocale cu un timbru similar, se reduc la șapte. Sistemul, devenit asimetric (patru vocale anterioare faţă de trei vocale posterioare), tinde să se simplifice în continuare prin eliminarea vocalei $[\varepsilon]$, care nu avea un corespondent posterior. În poziție accentuată, vocala în cauză se diftoghează în [je], iar în poziție neaccentuată se identifică cu [e].

Tabelul 1. Evoluția sistemului vocalic de la latină la romanica balcanică

\begin{tabular}{|c|c|c|c|}
\hline latina clasică & $\begin{array}{c}\text { latina populară } \\
\text { balcanică }\end{array}$ & \multicolumn{2}{|c|}{ romanica balcanică } \\
\hline & & $\begin{array}{c}\text { silaba } \\
\text { accentuată }\end{array}$ & $\begin{array}{c}\text { silaba } \\
\text { neaccentuată }\end{array}$ \\
\hline$\overline{\mathrm{u}}$ & $\mathrm{u}$ & $\mathrm{u}$ & \\
\hline $\mathrm{u}$ & $\mathrm{o}$ & $\mathrm{o}$ & $\mathrm{u}$ \\
\hline$\overline{\mathrm{o}}$ & $\mathrm{a}$ & $\mathrm{a}$ & $\partial$ \\
\hline $\mathrm{o}$ & $\varepsilon$ & $\widehat{\mathrm{ie}}_{\mathrm{j}} \mathrm{je}_{1}$ & $\mathrm{e}$ \\
\hline $\mathrm{a}, \overline{\mathrm{a}}$ & $\mathrm{e}$ & $\mathrm{e}$ & \\
\hline $\mathrm{e}$ & $\mathrm{i}$ & $\mathrm{i}$ & \\
\hline$\overline{\mathrm{e}}$ & & & \\
\hline $\mathrm{i}$ & $\mathrm{i}$ & & \\
\hline$\overline{1}$ & & & \\
\hline
\end{tabular}

Diftongarea $[\varepsilon]>[j e]$ se încadrează în vechea tendință de difongare a vocalelor accentuate, comună mai multor arii romanice, și corespunde difongării $[\varepsilon]>[j e]$, [0] > [wo] produse în spaniolă, franceză, italiană și retoromană. Așadar, fenomenul trebuie să fi avut loc în perioada romanică comună.

După trecerea vocalei $[\varepsilon]$ în [je], s-a reconstituit simetria sistemului vocalic, cel puțin în poziție accentuată, pentru că [je] se poate interpreta ca o secvență difonematică compusă din semivocala [j] şi vocala [e]. În balcanoromanica comună, a apărut însă un nou $[\varepsilon]$, provenit din metafonia vocalei [e] înaintea vocalei [e], [ə] sau [a] în silaba următoare, din care a rezultat, în cele din urmă, diftongul [ěa]. Procesul este paralel cu metafonia $[0]>[0]$ și diftongarea $[0]>[$ ŏa], produse în aceleași condiții fonetice. La început de cuvânt și de silabă, diftongii [ěa] și [ŏa] trec, totuși, în [ja] și [wa]. Așadar, realizările [ěa] și [ŏa] sunt ocurente numai în poziție postconsonantică, iar secvențele respective pot fi interpretate, eventual, ca o consoană palatalizată sau labializată urmată de vocala [a]. De vreme ce metafonia I (cea balcanoromanică) afectează atât vocala anterioară, cât și corespondentul ei posterior, metafonia II (românească) are loc numai în cazul diftongilor anteriori [ěa] și [ja], care devin [e] și [je $]_{2 a, b}$. 
Tabelul 2. Evoluţia vocalei [e] și diftongului [je] în poziție accentuată postconsonantică

\begin{tabular}{|c|c|c|c|c|c|c|c|c|c|c|}
\hline & & \multicolumn{4}{|c|}{ metafonia balcanoromanică } & \multicolumn{3}{|c|}{ metafonia românească } & & \\
\hline \multirow[t]{3}{*}{$e$} & \multirow[t]{3}{*}{$\varepsilon$} & \multirow{3}{*}{\multicolumn{2}{|c|}{$\begin{array}{c}\text { ie } \\
(+\mathrm{a}, \partial, \mathrm{e})\end{array}$}} & \multicolumn{4}{|c|}{ 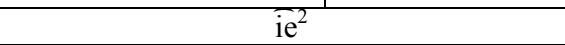 } & $\mathrm{je}_{1}$ & ie & 1 \\
\hline & & & & \multirow[t]{2}{*}{$\overline{\mathrm{i} \varepsilon}$} & iěa & \multirow[t]{2}{*}{ ia } & \multirow{2}{*}{$\begin{array}{l}(+a, \partial) \\
(+e)\end{array}$} & ja & $i a$ & 2 \\
\hline & & & & & & & & $\mathrm{je}_{2 \mathrm{a}}$ & $i e$ & 3 \\
\hline $\bar{e}$ & \multirow[t]{3}{*}{$\mathrm{e}$} & \multirow[t]{3}{*}{$\mathrm{e}$} & \multirow{3}{*}{$\begin{array}{l}(+\mathrm{i}, \mathrm{u}) \\
(+\mathrm{a}, \partial, \mathrm{e})\end{array}$} & \multicolumn{5}{|c|}{$\mathrm{e}^{3}$} & $e$ & 4 \\
\hline \multirow[t]{2}{*}{$i$} & & & & \multirow[t]{2}{*}{$\varepsilon$} & \multirow[t]{2}{*}{ ĕa } & & \multirow{2}{*}{$\begin{array}{l}(+\mathrm{a}, \partial) \\
(+\mathrm{e})\end{array}$} & ĕa & $e a$ & 5 \\
\hline & & & & & & & & $\mathrm{e}$ & $e$ & 6 \\
\hline
\end{tabular}

\begin{tabular}{|c|c|c|c|c|c|c|c|c|}
\hline fervo & ferbu & fierbu & & & & fjerb & fierb & 1 \\
\hline fervat & ferbo & fierbə & fierbo & fiěarbə & fiarbə & fjarbə & fiarbă & 2 \\
\hline fervit & ferbe & fierbe & ficrbe & fiěarbe & fiarbe & fjerbe & fierbe & 3 \\
\hline siccum & seku & & & & & sek & sec & 4 \\
\hline sēram & sero & & scro & sěaro & & & seară & 5 \\
\hline pirae & pere & & pere & pěare & & pere & pere & 6 \\
\hline
\end{tabular}

Tabelul 3. Evoluţia vocalei [e] și diftongului [je] în poziție accentuată inițială

\begin{tabular}{|c|c|c|c|c|c|c|c|c|c|c|}
\hline & \multirow{4}{*}{$\varepsilon$} & \multicolumn{4}{|c|}{ metafonia balcanoromanică } & \multicolumn{3}{|c|}{ metafonia românească } & \multirow[b]{2}{*}{$i e$} & \multirow[b]{2}{*}{1} \\
\hline \multirow[t]{3}{*}{$e$} & & \multirow[t]{3}{*}{ ie } & \multirow{3}{*}{$\begin{array}{l}(+\mathrm{i}, \mathrm{u}) \\
(+\mathrm{a}, \partial, \mathrm{e})\end{array}$} & \multicolumn{5}{|c|}{$\mathrm{je}_{1}$} & & \\
\hline & & & & \multirow[t]{2}{*}{$\mathrm{j} \varepsilon$} & \multirow[t]{2}{*}{ jĕa } & \multirow[t]{2}{*}{$\mathrm{Ja}$} & \multirow{2}{*}{$\begin{array}{r}(+\mathrm{a}, \partial) \\
(+\mathrm{e})\end{array}$} & ja & $i a$ & 2 \\
\hline & & & & & & & & $\mathrm{je}_{2 \mathrm{a}}$ & $i e$ & 3 \\
\hline $\bar{e}$ & \multirow[t]{3}{*}{$\mathrm{e}$} & \multirow[t]{3}{*}{$\mathrm{e}$} & \multirow{3}{*}{$\begin{array}{l}(+\mathrm{i}, \mathrm{u}) \\
(+\mathrm{a}, \partial, \mathrm{e})\end{array}$} & \multicolumn{2}{|l|}{$\mathrm{e}$} & \multicolumn{3}{|c|}{$\mathrm{je}_{3}$} & $e$ & 4 \\
\hline \multirow[t]{2}{*}{$i$} & & & & $\varepsilon$ & ěa & ja & $(+a, \partial)$ & ja & $e a$ & 5 \\
\hline & & & & & & & $(+\mathrm{e})$ & $\mathrm{je}_{2 \mathrm{~b}}$ & $e$ & 6 \\
\hline
\end{tabular}

\begin{tabular}{|c|c|c|c|c|c|c|c|c|}
\hline haedum & $\varepsilon d u$ & iedu & \multicolumn{3}{|l|}{ jedu } & jed & ied & \multirow{6}{*}{1} \\
\hline ego & $\varepsilon \mathrm{\varepsilon u}$ & ieu & \multicolumn{3}{|c|}{ jew } & & $e u$ & \\
\hline *estis> $>$ estī & $\varepsilon \int \mathrm{ti}$ & ie $\int t i$ & & & & $j e \int t^{j}$ & ești & \\
\hline est & $\varepsilon$ & ie & \multicolumn{3}{|c|}{ je } & & $e$ & \\
\hline et & $\varepsilon$ & ie & \multicolumn{2}{|c|}{ je } & & & & \\
\hline *exio & \multicolumn{7}{|c|}{ v. mai jos } & \\
\hline equam & $\varepsilon p \curvearrowright$ & iepə & јєрә & јӗарә & јарә & & iapă & \multirow[t]{2}{*}{2} \\
\hline eram & \multicolumn{7}{|c|}{ v. mai jos } & \\
\hline equae & $\varepsilon p e$ & iepe & jepe & jĕape & jape & jepe & iepe & \multirow[t]{2}{*}{3} \\
\hline *estit & $\varepsilon s t e$ & ieste & jeste & jĕaste & jaste & jeste & este & \\
\hline illu & \multirow{2}{*}{\multicolumn{4}{|c|}{$\begin{array}{l}\text { elu } \\
\text { ei }\end{array}$}} & \multirow{2}{*}{\multicolumn{2}{|c|}{$\begin{array}{l}\text { jel } \\
\text { jej }\end{array}$}} & el & \multirow[t]{2}{*}{4} \\
\hline illī & & & & & & & $e i$ & \\
\hline illa & \multirow{2}{*}{\multicolumn{2}{|c|}{$\begin{array}{l}\text { ea } \\
\text { ele }\end{array}$}} & & ĕa & \multicolumn{2}{|c|}{ ja } & $e a$ & 5 \\
\hline illae & & & cle & ěale & jale & jele & ele & 6 \\
\hline
\end{tabular}

În silaba inițială neaccentuată, evoluția acestor vocale este diferită: [e] (după o consoană) sau [a] ori zero fonetic (la iniţiala absolută).

\footnotetext{
2 Înaintea lui [n], trece în [i], de ex. lat. bene $>$ [bene] $>$ [biene] $>$ rom. bine.

${ }^{3}$ În unele contexte, trece ulterior în [ə], [i] sau [i] , de ex. lat. pilum $>$ [peru] $>$ rom. păr, lat. vēnae $>[$ vene] $>$ rom. vine, lat. vēnam $>$ [venə] $>$ rom. vână.
} 
Tabelul 4. Evoluţia vocalei [e] în poziţie neaccentuată postconsonantică

\begin{tabular}{|c|c|c|c|}
\hline latina & latina populară & romanica balcanică & româna \\
\hline$e$ & $\varepsilon$ & $\mathrm{e}^{4}$ & $e$ \\
\cline { 1 - 1 }$i$ & $\mathrm{e}$ & & \\
\cline { 1 - 2 } & & & \\
\hline
\end{tabular}

\begin{tabular}{|l|l|l|l|}
\hline \multicolumn{1}{|c|}{ latina } & \multicolumn{1}{c|}{ latina populară } & \multicolumn{1}{c|}{ romanica balcanică } & româna \\
\hline vervēcum & berbeku & berbeku & berbec \\
\hline vidēmus & vedemu & vedemu & vedem \\
\hline
\end{tabular}

Tab. 5. Evoluţia vocalei [e] în poziţie neaccentuată inițială

\begin{tabular}{|c|c|c|c|c|}
\hline latina & latina populară & \multicolumn{2}{|c|}{ romanica balcanică } & româna \\
\hline $\mathrm{e}$ & $\varepsilon$ & $\mathrm{e} \quad(+\mathrm{ksC})$ & - & - \\
\cline { 1 - 1 } & $\mathrm{e}$ & $(+\mathrm{r}, 1 ;$ în eccum $)$ & $\mathrm{a}$ & $a$ \\
\hline $\mathrm{i}$ & & & & \\
\hline
\end{tabular}

\begin{tabular}{|c|c|c|c|c|}
\hline latina & latina populară & \multicolumn{2}{|c|}{ romanica balcanică } & româna \\
\hline extīnguō & $\varepsilon$ stingu & estingu & stingu & sting \\
\hline exspectō & Espektu & espeptu & afteptu & aștept \\
\hline éricium & eriffu & eriffu & arifu & arici \\
\hline êlligere & eledzere & eledzere & aledgere & alegere \\
\hline
\end{tabular}

\subsection{FORMELE $E U, E S T T I, E-\left[\mathrm{JE}_{1}\right]$}

Diftongării romanice i se poate atribui apariția diftongului [je] din pronumele $e u$ și formele verbale ești, e. Astfel, acestea ar reprezenta o evoluție fonetică regulată, ca în cuvinte precum ieri, fier, mieu (refăcut ulterior în meu), având paralele exacte în spaniolă, în care lat. $e$ se diftonghează atât în silabe deschise, cât și în închise (ca în română) ${ }^{5}$, și paralele parțiale în italiană și franceză, în care diftongarea se produce numai în silabe deschise.

Tratamentul vocalei depinde în acest caz de gradul ei de deschidere și de locul accentului și nu de poziţia pe care o ocupă în cuvânt (la iniţială sau în interior), de aceea, nimic nu împiedică diftongarea, existând condiții necesare acesteia.

Din păcate, niciuna dintre celelalte limbi romanice în care s-a produs diftongarea nu demonstrează că aceasta a avut loc în cazul pronumelui ego. Acest lucru se datorează faptului că pronumele ego a avut o evoluție dublă de la latină la limbile romanice, existând două variante, uneori chiar în cadrul unei singure limbi

\footnotetext{
${ }^{4}$ În unele contexte, trece ulterior în [ə] sau [i], de ex. venare $>$ [vinare] > rom. $a$ vâna, lat. pop. ${ }^{*}$ veraticum $>[$ veratik] $>$ rom. văratic.

${ }^{5}$ Cf. rom. iederă, iapă (< [jepə]), iarbă (< [jerbə]), ieri, fier, piele, piatră (< [pjetrə]), bine $(<$ [bjene]) și sp. hiedra, yegua, hierba, ayer, hierro, piel, piedra, bien.
} 
(ca în română). Forma de bază, ego, a evoluat mai întâi spre [عo $]^{6}$ și ulterior s-a scindat în două forme, una cu accentul pe prima silabă și alta cu accentul pe cea de-a doua. Vocalele neaccentuate au trecut într-o semivocală (sau chiar într-o consoană), cuvântul devenind monosilabic. Portugheza, occitana și retoromana au optat pentru prima variantă (port. eu [ew], occ. ieu [jew], surs. jeu [jew]), iar spaniola, catalana, franceza și dalmata - pentru cea de-a doua (sp. yo [jo] $>$ [ḑo] / [30]; cat. jo [30]; fr. jo [ḑo] > je [3ə]; dalm. ju [ju]). Româna cunoaște, de fapt, ambele forme, cea standard $e u$ [jew] și cea populară io [jo], precum franceza veche în care sunt atestate formele: cea accentuată gié $(<j e o<i e o)$ și cea neaccentuată je $(<j o)$ (Borodina, 1965: 107). Singurele paralele cu româna, cea occitană și retoromană, nu reprezintă un argument decisiv, pentru că diftongarea din aceste limbi are caracter destul de neregulat și diftongul [je] din occ. ieu și surs. jeu poate avea o altă origine - ar putea fi vorba, totuși, despre o preiotare, mai ales în occitană (în perioada medievală este ocurentă mai degrabă forma $e u$ ). Vocala $[\varepsilon]$ din $e u$ s-ar fi închis acolo (și în portugheză) sub influența lui [w]. Cu toate acestea, pronunția „preiotată" a pronumelui $e u$ din română poate fi explicată prin diftongarea romanică: lat. ego $\left[\varepsilon_{0}\right]>[\varepsilon 0]>[\widehat{\mathrm{ieu}}]>[\mathrm{jew}]$ 'eu', din moment ce există exemple pentru diftongarea vechiului $[\varepsilon]$ accentuat inițial atât în română, cât și în alte limbi romanice (sp. ayer, occ. ièr, fr. hier, rrom. ier, it. ieri, rom. ieri). Din punct de vedere istoric ar fi vorba de același difong ca în ieri, ied, ierburi și alte forme similare, numai că, spre deosebire de ele, acesta nu este notat $i e$, ci $e$. Din aceeaşi categorie fac parte formele verbului a fi: e și ești. Prima este o continuare a lat. est, iar a doua - a formei analogice *estī. Aici se încadrează și conjuncția românească veche $e<$ lat. et 'și' (cf. arom. e).

\subsection{FORMELE ESTE, ERAM- [ $\left.\mathrm{JE}_{2 \mathrm{~A}}\right], E L E-\left[\mathrm{JE}_{2 \mathrm{~B}}\right]$}

În ceea ce privește formele este, era (la fel și eram, erai, erați, erau) și ele, fonetismul [jeste], [jera], [jele] reprezintă o inovație. Formele precedente, atestate chiar în primele texte românești din secolul al XVI-lea și folosite până în secolul al XIX-lea, sunt iaste, iara (la fel și iaram, iarai, iarați, iarau), iale, a căror valoare fonetică, sau mai degrabă stabilitatea ei, nu este sigură. Cel puțin inițial, pronunția lor trebuia să fie [jale], [jaste] și [jara], conform formei grafice, evoluând după aceea $^{7}$ spre pronunția actuală. Regional, se mai păstrează fonetismul inițial, ocurent de altfel și în aromână. $\mathrm{Cu}$ alte cuvinte, diftongul [je] din aceste forme nu este un [e] preiotat, ci reprezintă un stadiu ulterior al diftongului [ja]. Acesta, la rândul lui, constituie o evoluție normală a vocalelor inițiale din etimoanele latine ale formele respective: *estit, erat și illae, deși fiecare dintre ele reprezintă un caz puțin diferit.

\footnotetext{
${ }^{6} \mathrm{Cf}$. sard. (d)eo [(d)eo], it. io [io].

${ }^{7}$ Datarea procesului: Keleman, 1964: 183-186; Avram, 1964: 1-5, 38-45.
} 
În evoluția imperfectului de la $a f i$, paralelă, în principiu, cu cea a unor forme precum lat. equam, intervin mai multe procese analogice. În primul rând, fonetismul primei silabe, dacă aceasta era neaccentuată, a fost refăcut după cel al silabei accentuate ([ja] în loc de [a]). În al doilea rând, desinențele etimologice ([ə], [ə]/ [aj], [ə], [am], [ats] , [ə]) au fost înlocuite cu desinențele normale de imperfect ale altor verbe (['am], ['aj], ['a], ['am], ['atsi], ['aw]). Ca urmare a acestor schimbări, diftongul [ja] și-au pierdut accentul și a trecut în diftongul [je], prin analogie cu forme ca iarnă ['jarnə] - iernatic [jer'natik].

Tabelul 6. Evoluția formelor de imperfect ale verbului a fi

\begin{tabular}{|c|c|c|c|c|c|c|c|c|c|}
\hline latina & \multicolumn{2}{|c|}{ latina populară } & \multicolumn{5}{|c|}{ romanica balcanică } & \multicolumn{2}{|c|}{ româna } \\
\hline eram & ${ }^{1} \varepsilon \mathrm{r} \partial$ & Fierə & ljerə & liěarə & ljarə & ljara & $\mathrm{ja}^{\mathrm{l}} \mathrm{ra}(\mathrm{m})$ & jelram & eram \\
\hline eras & ${ }^{1} \varepsilon \mathrm{r} \partial$ & lierə & ljerə & ljĕarə & ljarə & ljaraj & jalraj & jelraj & erai \\
\hline erat & ${ }^{1} \varepsilon \mathrm{r \partial}$ & †ierə & ljerə & ljĕarə & ljarə & ljara & jalra & jelra & era \\
\hline eramus & elramu & $\mathrm{a}^{1}$ ramu & $\mathrm{a}^{\mathrm{l}} \mathrm{ramu}$ & $a^{1}$ ramu & jal'ramu & jalram & jalram & jelram & eram \\
\hline eratis & e'rati & alratsi & a'ratsi & $a^{1}$ ratsi & jal'ratsi & jal rats $^{j}$ & jalrats $^{\mathrm{j}}$ & jelrats $^{\mathrm{j}}$ & erați \\
\hline erant & ${ }^{1} \mathrm{cr} \partial$ & 1ิerə & ljerə & ljĕarə & jarə & ljara & jalra(w) & jelraw & erau \\
\hline
\end{tabular}

Stadiul cu [ə] nefiind atestat, este posibil ca desinențele analogice să fi fost introduse în paradigma imperfectului deja în această etapă. În orice caz, accentul a rămas inițial pe prima silabă (cel puțin pentru persoanele 1., 2., 3. singular și 3 . plural), pentru că numai astfel se poate explica trecerea lui $e$ latin în [ja]. În afară de aceasta, persoanele 1. și 2. plural ar fi putut să-și mute accentul pe prima silabă, prin analogie cu celelalte forme, deja în perioada romanică (în loc să admitem refacerea lor analogică ulterioară), pentru că fonetismul așteptat cu [a] iniţial $(<[\mathrm{e}]$ neaccentuat) nu a fost notat nici în Romania balcanică, nici în alte arii romanice. Remarcăm că formele din spaniola standard era, eras etc. sunt excepționale (Perlin, 2004: 101) - în asturiană, de ex., se folosesc forme aşteptate ca yera, yeres (2001, Gramática: 202). Astfel de fonetisme sunt ocurente în franceza veche, de ex. ier, iers, concurate și acolo de er, ers (Sypnicki, 1977: 79).

\subsection{FORMELE $E L, E I-\left[\mathrm{JE}_{3}\right]$}

Atât [e], care continuă $\bar{e}$ și $i$ din latină, cât și $[\varepsilon]$, provenit din lat. $e$, dacă se aflau în poziție initială accentuată, au evoluat în română, în majoritatea cazurilor, spre [je] sau [ja]. O excepție o constituie cuvintele care începeau cu [e] după care în silaba următoare se afla vocala [u] sau [i]. Totuși, și în acestea, la un moment dat, vocala inițială [e] a devenit [je], ceea ce nu este explicabil în baza anologiilor din română sau alte limbi romanice. În română, vocala [e] (< lat. $\bar{e}$ sau $i$ ) înaintea unui [u] sau [i] din silaba următoare, în mod normal, adică după o consoană, nu se diftonghează, cf. siccum > [sek]. În alte limbi romanice (în franceză și retoromană), 
diftongarea se produce, dar cu un rezultat diferit (diftongul descendent [ej]) şi nu poate constitui un reper pentru română.

Așadar, numai în acest caz ([je $\left.]_{3}\right)$ s-ar putea vorbi, eventual, despre o preiotare propriu-zisă, mai ales că aceasta nu este redată în scris - de data aceasta se pare că în mod justificat. O reprezintă următoarele forme: pronumele $e l$ și pluralul acestuia

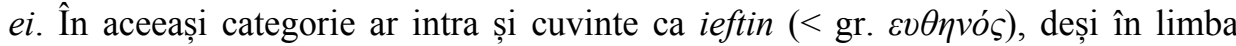
contemporonă este scris cu ie. În româna veche, numărul lor a fost mai mare. Majoritatea sunt de orgine greacă, dar au pătruns în română prin filiera slavonă: eres, eretic, Evanghelie, evreu, evreică, Ecaterina, Eftimie, Elena, Elisaveta, Evdochia, Eghipet, Evropa. Din slavonă sau dintr-o altă limbă slavă provin: particula afirmativă $e i$ 'da', iesle și iezer.

Cuvântul iesle a fost împrumutat ca iasle, care reproduce forma slav. jasli, și a suferit ulterior aceeași metafonie ca iaste - prin urmare, ie reprezintă acolo [je $]_{2 \mathrm{a}}$. În schimb, iezer (slav. jezer) avea și varianta iazer, prin analogie cu cuvinte ca iaste, ajungând, în cele din urmă, tot prin metafonie, la forma etimologică iezer.

Pronunția lor preiotată este confirmată de ezitări între literele $\iota \epsilon$ și $\epsilon$, cf. grafii ca le și $\epsilon$ (Frâncu, 2009: 96-97) pentru [je] (verbul 'e'), evanghelie și ievanghelie, evreu și ievreu sau chiar forme hipercorecte precum Erusalim în loc de Ierusalim.

În alfabetul chirilic se făcea inițial o distincție între literele $l \epsilon$ și $\epsilon$, pentru diftongul [je] și, respectiv, vocala [e], dar cea dintâi a ieșit practic din uz, iar valoarea fonetică [je] a început să fie exprimată de litera $\epsilon$ (Calotă, 1986: 41). Cu alte cuvinte, litera $\epsilon$ de la început de cuvânt putea reprezenta atât vocala [e], cât și diftongul [je]. O dovadă în plus o constituie etimoanele slavone ale cuvintelor respective pronunțate și ele cu [je]. În afară de aceasta, în unele texte, se folosesc două variante ale slovei nepreiotate: $\epsilon$ pentru [je] și $\epsilon$ pentru [e] (v. mai jos, 2.2). Așadar, optăm mai degrabă pentru pronunția [je] și în cazul în care se folosea litera $\epsilon$.

În perioada fanariotă, în care slavona a cedat locul limbii grecești, româna a împrumutat o serie de termeni direct din greacă, de ex. egumen, episcop, epitrop. În cazul lor, $e$ inițial nu se mai pronunța [je]. Același lucru este valabil și pentru turcisme, de ex. efendi. Mai mult decât atât, cuvântul turcesc yedek a fost adoptat ca $e d e c$, deci cu refacerea diftongului inițial în $e$,nepreiotat"” (Sala, 1989: 252).

În perioada reromanizării, numărul cuvintelor cu [e] iniţial s-a mărit considerabil. Unele au dublat împrumuturi mai vechi din greacă prin slavonă sau leau influențat fonetismul. Astfel, sub influența franceză (sau latină) s-a refăcut pronunția unor cuvinte ca eretic, Evanghelie, evreu, Elena (fr. hérétique, Évangile, hébreu, Hélène) sau chiar forma lor: Elisabeta, Egipt, Europa. Celelalte și-au modificat fonetismul în mod analogic. Prin urmare, în româna de astăzi, singurele exemple pentru preiotarea propriu-zisă rămân câteva cuvinte izolate ca $e l, e i$, ieftin, eventual iezer (unele scrise cu $e$, altele cu $i e$ ).

\footnotetext{
${ }^{8}$ Totuși, în ienibahar (< tc. yeni bahar), diftongul a fost păstrat.
} 


\subsection{FORMA EI (DAT. F. SG.) - [ $\left.\mathrm{JE}_{4}\right]$}

Ultima dintre formele în cauză, pronumele feminin $e i$, nu reprezintă nici o diftongare propriu-zisă, nici preiotare. În acest caz, iotul are origine consontantică.

Deși acest lucru nu s-a produs în condiții fonetice identice, și în romanica balcanică, precum în restul Romaniei, au apărut consoanele palatale $[n]$ și $[K]$. În Balcani, cele două foneme noi sunt un rezultat al palatalizării consoanelor [n] și [1] înaintea vocalei [i] sau semiconsoanei [j] (provenită ori din lat. [i] sau [e] în hiat, ori din diftongarea romanică).

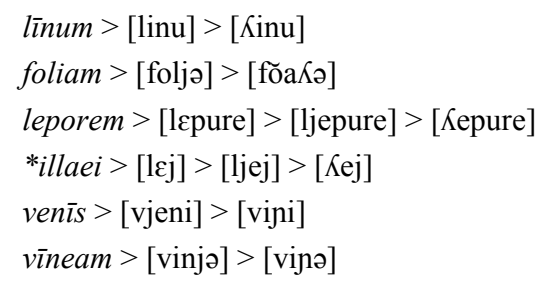

În română, deja în perioada preliterară, ambele consoane au trecut în [j], cu excepția graiurilor bănățene în care palatala [n] s-a menținut. Dacă vocala următoare era [e], se forma un nou diftong [je]4. Diftongul [ji], mai ales la inițiala cuvântului, devine [i] în româna standard.

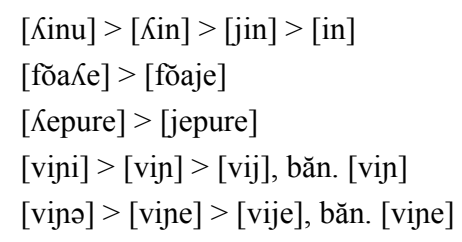

Făcând abstracție de [n], procesul amintește de trecerea fr. $[K]$ în [j], care, totuşi, s-a încheiat abia în a doua jumătate a secolului al XIX-lea (Sypnicki, 1977: 197), și cu fenomenul de yeísmo din spaniolă, care a început mult mai devreme, în secolul al XV-XVI-lea, dar nici acum nu s-a generalizat pe tot teritoriul hispanofon. În afara Romaniei, dar în directa vecinătate cu aria românească, fenomenul de trecere a lui $[K]$ în $[j]$ s-a produs în maghiară.

Celelalte idiomuri balcanoromanice păstrează fonetismul arhaic. Aceeași lucru este valabil și pentru pronumele feminin ei, căruia îi corespund acolo formele cu $[\Lambda]$ : istr., megl., arom. [Kepure].

Așadar, forma româneacă [jej], scrisă $e i$, trebuie juxtapusă cu forme ca [jepure], [jerta], [fóaje], scrise iepure, ierta, foaie, adică cu ie. La origine, este același pronume ca it. lei [lei] (ambele continuând forma reconstituită din latina populară, *illaei, specifică Romaniei italo-balcanice) și nu are nicio legătură cu sl. єєŭ [jej], în ciuda identității formale actuale. 


\section{ORIGINEA PREIOTĂRII PROPRIU-ZISE $-[\mathrm{JE}]_{3}$}

După eliminarea unui număr de forme pe care le-am explicat prin alte procese fonetice cunoscute, se mai pune în continuare problema originii preiotării propriuzise, adică a apariţiei diftongului „fals” [je $]_{3}$. Fonetisme mai vechi ca [jevanjelije] pot fi explicate prin forma etimoanelor slavone, dar pentru altele precum [jel], [jej], [jeftin], în cazul în care nu le considerăm analogice cu forme ca [jew], [jeftit, trebuie să căutăm o altă explicație. Ca în alte cazuri controversate din istoria limbii române, teoriile formulate cu privire la acest fenomen recurg ori la influența străină (în acest caz, la superstratul slav), ori la „forțele interne ale limbii”.

\subsection{TEORII EXISTENTE}

Teoria superstratului slav este acceptată de majoritatea lingviştilor români și străini (H. Tiktin, Al. Philippide, Al. Rosetti, E. Petrovici, V. Pisani, Em. Vasiliu, W. Mańczak, A. du Nay). Ivănescu (2000: 409) precizează că ,ar trebui să admitem de fapt numai o schimbare a bazei de articulaţie româneşti, prin amestec cu slavii".

În schimb, S. Puşcariu, Fr. Schuerr, M. Sala atribuie preiotarea acţiunii forţelor interne ale limbii. În favoarea acestei teorii s-au adus următoarele argumente:

1) în română apar și alte proteze, mai ales [w] înaintea lui [o], iar fenomenul nu poate fi separat de apariţia semiconsoanelor în interiorul cuvântului la început de silabă, de ex. [aleje], [speriwos] (Sala, 1970: 22),

2) pentru unele proteze din română $\left(\left[^{2}\right]\right.$ şi $\left[^{i}\right]$ care precedă vocalele centrale $[a]$, [ə], [i]]) nu poate fi invocată o explicație externă (Sala, 1970: 23),

3) dialectal, preiotarea apare și în alte limbi romanice: dalmată, italiana de sud, spaniolă, catalană, occitană (Lausberg, 1956: 117; Nandriș, 1963: 214; Sala, 1970: 22; Sala, 1989: 252).

Pușcariu explică protezele prin fonetică sintactică, adică „prin tendința de a evita hiatul prin intercalarea unei semivocale între finala vocalică a unui cuvânt $[e]$ sau $[u]$ cu care începea cuvântul următor" (Sala, 1970: 22). Sala, care consideră procesul ca fiind analogic cu eliminarea hiatului interior prin dezvoltarea unui sunet de tranziție, atribuie ambele fenomene tendinței „,de de întărire a elementelor iniţiale de silabă" (Sala, 1970: 22).

Din această teorie trebuie reținute următoarele premise:

1) preiotarea este paralelă cu apariția altor proteze și trebuie analizată împreună cu acestea,

2) atât protezele, cât și epentezele semiconsonantice exprimă tendința de evitare a hiatului prin întărirea elementului inițial de silabă.

Întrebarea la care urmează să răspundem prin analiza fenomenului de proteze din limbile sus-menționate este în ce măsură situația din română trebuie sau poate să fie pusă în legătură cu cea din alte limbi romanice sau din limbile slave. 


\subsection{PROTEZE ÎN LIMBILE ROMANICE ȘI SLAVE}

În ceea ce privește protezele atestate pentru alte limbi romanice, acestea nu apar decât regional și neregulat, „mai ales la vocale ca $a, o, u$ ” (Sala, 1989: 252). În occitană, protezele sunt atestate pentru regiunile Landes și Roussillon (Nandriș, 1963: 214). Proteza [w] mai există în provensală înainte de [0], dar acolo este vorba mai degrabă de difontgarea acestei vocale care se produce și în poziție postconsonantică, mai ales că rezultatul ei este, pe lângă [wo], și [we], și [wa], cf. ort $[\mathrm{W} O \mathrm{R}] \sim[\mathrm{weR}] \sim[\mathrm{waR}]$ vs. mòrt $[\mathrm{mw} \mathrm{TR}] \sim[\mathrm{mweR}] \sim[\mathrm{mwaR}]$ (Martin, Moulin, 1998: 18-19). Singura proteză mai sigură din provensală este [v] înainte de [0], diftongat sau nu, de ex. òc [vwa] 'da' (Martin, Moulin, 1998: 28) și, eventual, [j] în pronumele ieu. Segmentul inițial uò [wo] > [jo], atestat pentru o arie mai mare a occitanei reprezintă, de fapt, tot o diftongare neregulată, cf. uòu [jow] 'ou' și fuòc [fjo] 'foc'.

În grupul iberoromanic, o posibilă preiotare este ocurentă în pronunția port. eu [jew] în graiul din Porto și în general, în portugheză, în fonetica sintactică, de ex. onde é? [õdi je]. Inițialul [je] din asturiană sau aragoneză reprezintă, de fapt, o diftongare romanică a vechiului $[\varepsilon]$, cf. lat. est $>$ ast., arag. ye vs. lat. iste $>$ ast. esti.

Un caracter mai regulat îl au numai protezele din italiana de sud și dalmată. Pentru Italia de sud, conform lui Lausberg (1956: 117), sunt atestate protezele [j] (înainte de [e] și [i]) și [y] (înainte de [a], [o] și [u]), de ex. illum > [jillu], hominem $>$ [ðəommine]. Pentru vegliotă, Bartoli (2000: 415) notează protezele: [j], care poate apărea înainte de toate vocalele inițiale accentuate, și [v], care se produce înainte de [wa], acest segment trecând ulterior în [va] și [gwa], de ex. animam $>$ [jamna], arborem $>$ [jwarbul], illum $>$ [jal], alterī $>$ [jiltri], ünum $>$ [jojn], ambula $>$ [junda], octo $>$ [vapto] $\sim$ [gwapto].

În limba română, conform lui Vasiliu (1965), nu numai [e] iniţial, care poate fi preiotat, ci și alte vocale inițiale pot fi precedate de o proteză semiconsonantică (,apendice asilabic"), în funcție de locul de articulare a vocalei respective. Astfel, înainte de vocalele anterioare [e] și [i] apare proteza $\left.{ }^{\mathrm{j}}\right]$, înainte de cele posterioare, $[\mathrm{o}]$ și $[\mathrm{u}]$ - proteza $\left[{ }^{\mathrm{W}}\right]$, iar înainte de cele centrale, [a], [ə], [i] - proteza $\left[^{2}\right]$ sau $\left[^{\mathrm{i}}\right]$. Protezele centrale, potrivit lui Sala (1970: 23), apar mai degrabă la nivel dialectal. În afară de aceasta, în anumite graiuri (Banat și Hunedoara), pentru vocala [a] este atestată proteza $\left[{ }^{j}\right]$ (Ivănescu, 1980: 412).

Tabelul 7. Protezele semiconsonantice din limba română și repartizarea acestora

\begin{tabular}{|c|c|c|}
\hline $\mathrm{j}$ & $\partial \sim \dot{f}$ & w \\
\hline $\mathrm{i}$ & $\dot{i}$ & $\mathrm{u}$ \\
\hline $\mathrm{e}$ & $\partial$ & $\mathrm{o}$ \\
\hline & $\mathrm{a}$ & \\
\hline
\end{tabular}


Inițial, asemenea proteze apăreau numai la cuvintele din fondul vechi: acest

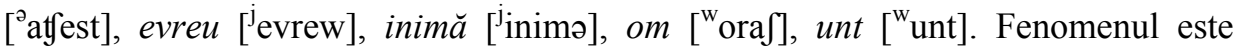
atestat chiar în unele din primele texte românești. Psaltirile Șcheiană şi Hurmuzaki întrebuințează $\epsilon$ în loc de $\epsilon$ la început de cuvânt și de silabă, adică acolo unde și astăzi se pronunță [je] / [je] (Candrea, 1916: CXXII). În alte situații, avem litera $\epsilon$. De asemenea, în Codicele Voronețean, slova $G$ apare la început de cuvânt și de silabă, deci tot acolo unde în vorbirea populară se pronunță [wo] / [ ${ }^{w}$ o], în alte poziții folosindu-se $O$ (Sbiera, 1885: 300).

În schimb, neologismele din perioada reromanizării se pronuțau cu vocale „pure”, nealterate: artă [artə], epocă [epokə], imn [imn], operă [operə], util [util]. S-a creat, asftelf, o distincție între cele două grupuri de cuvinte, care a putut fi respectată, de fapt, numai de vorbitorii culți:

acest [ ${ }^{2}$ atfest] vs. artă [artə]

evreu [ $\left.{ }^{\mathrm{j}} \mathrm{evrew}\right]$ vs. epocă [epokə]

inimă [ ${ }^{\mathrm{j}}$ nimə] vs. imn [imn]

om [ $\left.{ }^{\mathrm{w}} \mathrm{Om}\right]$ vs. operă [operə]

unt [wunt] vs. util [util]

Prin urmare, în vorbirea populară, pronunția cu proteze s-a extins și la neologisme: artă [ ${ }^{\partial}$ artə], epocă $\left[{ }^{\mathrm{j}}\right.$ epokə], imn [ $\left.{ }^{\mathrm{j}} \mathrm{imn}\right]$, operă $\left[{ }^{\mathrm{w}}\right.$ operə], util [ $\left.{ }^{\mathrm{w}} \mathrm{util}\right]$. În vorbirea cultă, în schimb, s-a impus pronunția fără proteze și în cazul cuvintelor mai vechi, devenind ulterior o pronunție standard (Vasiliu, 1965: 96): acest [atfest], nu [ ${ }^{\curvearrowright}$ atfest], epocă [epokə], nu [ ${ }^{\mathrm{j}}$ epokə], inimă [inimə], nu [inimə], oraş [ora $]$ ], nu [ ${ }^{\mathrm{w}}$ ora $]$ ], unt [unt], nu [ ${ }^{\mathrm{w}}$ unt]. De fapt, cele două pronunții coexistă în continuare, prima fiind marcată ca populară (Sala, 2001: 455) sau chiar incultă, cu excepția lui [e] preiotat într-un număr de cuvinte, care s-a identificat, de fapt, cu diftongul [je] provenit din alte surse.

Eliminarea protezelor a afectat însă și cuvintele în care [je] iniţial trebuia păstrat în ciuda ortografierii lor cu $e$ (pronumele personale și formele verbului $a$ fi). Fenomenul are mai multe explicații: în primul rând intervine dorința vorbitorului de a evita pronunția incultă, care a fost întărită de influența ortografiei (Sala, 2001: 252) și, mai ales în ultimii ani, de influența altor limbi romanice ca spaniola sau italiana în care formele analogice cu cele românești sunt pronunțate fără [j] inițial, cf. sp. el [el] vs. rom. el [jel], sp. și it. era [era] vs. rom. era [jera], sau chiar port. eu [ew] vs. rom. eu [jew]. Astfel s-a ajuns la fonetisme hipercorecte ca [el], [era], [este], [ew], marcate stilistic ca pretențioase. Trebuie observat că, de ex., Vasiliu admite atât pronunţia cu un iot protetic, cât şi cea fără preiotare, acestea fiind facultative şi coexistând chiar în vorbirea aceluiaşi vorbitor: „De exemplu, idiolectul autorului cunoaşte ambele pronunţări”" (Vasiliu, 1965: 96).

Problemelor ortoepice li se adaugă și cele de ordin ortografic. După cum s-a spus, în alfabetul chirilic românesc, litera $e$ de la început de cuvânt putea însemna 
atât [e], cât și [je] (Calotă, 1986: 41). În majoritatea cazurilor, pronunția era [je], pentru că schimbările fonetice specifice limbii române au eliminat practic vocala [e] din poziţia iniţială. În puține cuvinte cu [e] iniţial, s-a adoptat, până la urmă, tot o pronunție ,preiotată”, întărită de fonetismul unor împrumuturi greco-slavone. În epoca fanoriotă, română a adoptat multe grecisme și turcisme, iar mai târziu, în perioada alfabetului de tranziție - un număr impresionant de neologisme latinoromanice, în care vocala iniţială $[\mathrm{e}]$ și-a păstrat pronunția etimologică, litera $e$ redând din nou două pronunții, una mai veche [je] și alta mai nouă [e]. În momentul adoptării alfabetului latin, transpunerea s-a bazat pe principiul fonetic: orice [e] a fost redat ca $e$, iar orice [je] - ca $\breve{e}$. Totuși, la un moment dat, într-o serie de cuvinte, secvența $\breve{l} e$ a fost înlocuită cu $e$, conform unor pretinse criterii etimologice, lucru care a complicat inutil scrierea. Justificarea „etimologică” este invocată și astăzi: „Principiului etimologic i se datoresc [...] scrierea cu $e$ a diftongului ie la iniţiala pronumelor personale eu, el, ei, ele și a unor forme de indicativ prezent (eşti, este, e) şi imperfect (eram, erai etc.) ale verbului a fì" (Sala, 2001: 405).

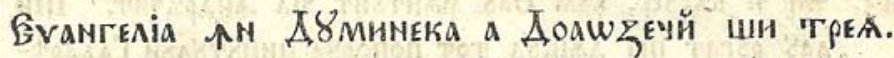

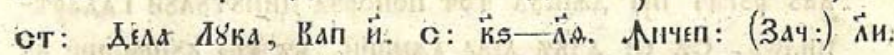

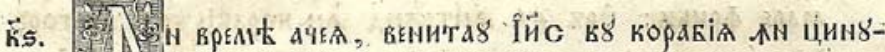

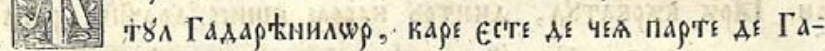

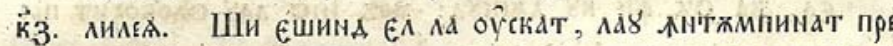

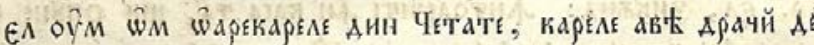

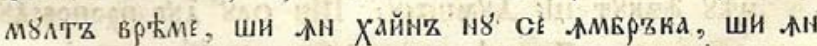

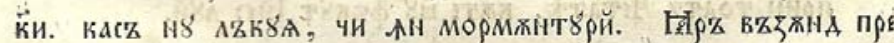

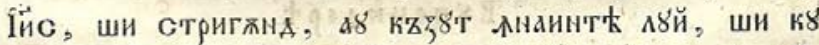

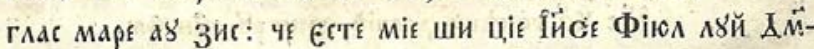

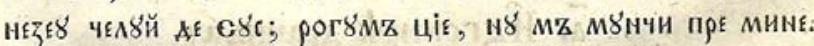

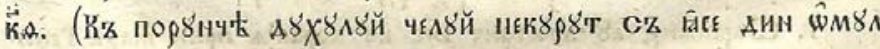

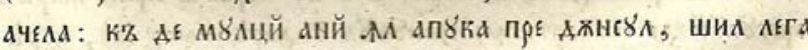

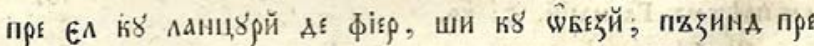

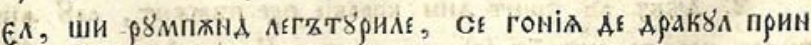

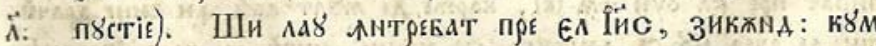

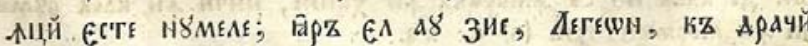

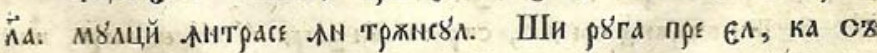

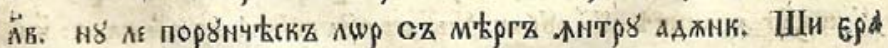
8

Pagină din Tâlcuiala Evangheliilor, Sibiu, 1857, în care diftongul inițial [je] este redat cu slova în toate cuvintele (Evanghelie, este, el, eșind). 
În istroromână, în poziția iniţială accentuată, vocala anterioară [e] poate primi proteza $[\mathrm{j}]$, iar vocalele posterioare $[\mathrm{a}],[\mathrm{o}]$ și $[\mathrm{u}]$ - proteza $[\mathrm{w}]$. Este adevărat că toate cuvintele care încep cu [e] / [je] sunt împrumuturi din italiană. Cuvintele din vechiul fond și cele împrumutate din croată încep cu [je], de ex. ied 'ied', iey 'ies', ier 'ieri', ie 'el', iesen 'toamnă'. Vocalele închise [i] și [u] pot fi precedate de proteza $[\mathrm{j}]$, respectiv [v], dar repartizarea lor are caracter mai complex. În unele cuvinte, proteza este obligatorie, de ex. $i$ [ji] 'a merge'; ima [jima] 'nume', în altele - facultativă, de ex. istina [jistina] [istina] 'adevăr', utå [vuta] [uta] 'a uita', iar în altele - inadmisibilă, de ex. istile [istile] 'acelaşi', invitęi [invitzj] 'a invita', $u d$ [ud] 'ud' (Kovačec, 1971: 52). Reparitiția nu ține cont de etimologia cuvintelor - în fiecare dintre cele trei categorii există atât cuvinte din vechiul fond, cât și împrumuturi. Fenomenul protezelor sau consolidarea acestuia trebuie pus pe seama influenței croate, lucru confirmat prin formele înseși ale protezelor, cu excepția unor cuvinte ca ied, iey etc., în care iotul este de aceeași origine ca în celelalte idiomuri balcanoromanice.

Protezele semiconsonantice apar și în meglenoromână. Înaintea lui [e] se produce [j], iar înaintea lui [o] - [w]. Prima proteză este mai puțin regulată: este ocurentă în mod sistematic la pronumele iel [jel], iestu [jestu] 'acesta', deci în latinisme, dar în ceea ce privește împrumuturile, de obicei coexistă două forme, de ex. ielă și elă 'un fel de arbore de munte' < bg. eлa, eftin și ieftin (Capidan, 1925: 103-104). Proteza [w], în schimb, precedă orice [o] inițial, de ex. uom [wom] (Capidan, 1925: 114).

În schimb, acestea nu sunt atestate în aromână, deși în ceea ce privește preiotarea lui [e] inițial, situația nu este foarte clară. Caragiu-Marioțeanu (1977: 177) afirmă că în aromână preiotarea nu a avut loc, spre deosebire de diftongarea spontană, explicând astfel fonetismele [el], pe de o parte, și [jed], [jes] pe de alta. Totuși, la Dalametra (1906: 114) ca variantă a lui el apare și iel, pe care Capidan (1932: 412) o neagă în mod explicit. Papahagi (1963), în schimb, nu cunoaște decât forma $e l$ și ne trimite de la ied, ies și iernare, iernedz la ed, es și irnare, irnedz, care se explică prin stadiul ernare, ernedz, la fel ca și ișim, ișii, ișeam, ișită etc., care trebuie să fi provenit din eșim, eșii, eșeam, eșită (cu transformarea automată $e>i$ provocată de schimbarea accentului). Singurele forme cu diftong pe care le notează Papahagi sunt iehlă 'brad', ieri și plurale ca ierghi, ieschi, în care iotul se menține sub influența singularelor iarbă, iască. Cuvântul ierosină 'preoție' se explică prin fonetismul etimonului său grecesc $\imath \varepsilon \rho \omega \sigma v ́ v \eta$ (cu hiat diftongat). Singurul corespondent al rom. ieftin este forma nepreiotată eftin. Prin urmare, se pare că în aromână s-au produs atât preiotarea, cât și diftongarea, dar ulterior diftongul [je] a fost eliminat în mod automat, indiferent de etimologia lui. Substantivul etă nu continuă, de fapt, lat. aetas (atunci ar fi devenit *iată, cf. equam > iapă), ci provine din alb. jetë prin stadiul ietă. Împrumuturi mai noi, de ex. eg 'arici' < bg.-mac. eж, 


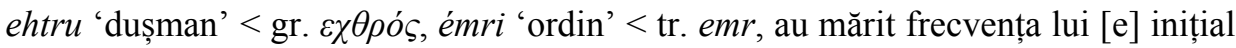
și au contribuit la eliminarea definitivă a formelor cu [je] la inițială.

Preiotarea din limbile slave face și ea parte dintr-un fenomen mai larg, cel al protezelor în general. La prima vedere, repartizarea acestora se prezintă destul de haotic. În general, vocalele anterioare sunt precedate de [j], iar cele posterioare - de [w] (> [v]) sau [gw]. Abaterile de la această schemă sunt, cel puțin în unele cazuri, condiționate istoric. Dublete ca [utro] [jutro] 'dimineață, mâine' se explică prin faza inițială [ytro] $>$ [jytro], cu vocala anterioară $[y]$. Vechiul $[u]>[i]$ primește proteza în mod obligatoriu. Noile vocale $[\mathrm{u}]$ și $[\mathrm{o}]$ sunt precedate de $[\mathrm{w}]$ sau $[\mathrm{v}]$ cel puțin în unele limbi sau dialecte. Ezitări ca $[\varepsilon] \sim[j \varepsilon]$ sau $[\mathrm{a}] \sim[\mathrm{ja}]$ au fost eliminate în favoarea pronunției nepreiotate în balcanoslava sudică și a celei preiotate în celelalte limbi slave. În cele din urmă, practic toate cuvintele care încep cu [e] sunt de origine străină. Cele care aparțin fondului lexical mai vechi se pronunță cu

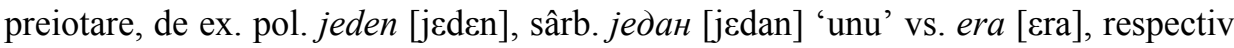
epa [cra] 'eră' (neologism).

\section{CONCLUZII}

Prin urmare, cele mai multe concordanțe există între limbile slave, pe de o parte, și limbi romanice ca dalmata și idiomurile balcanoromanice (româna, istroromâna și meglenoromâna), pe de alta. Fenomene slave precum o frecvență mai mare a protezei [j], de fapt apariția ei înaintea unor vocale non-anterioare, și proteza [gw], se reflectă în vegliotă. Proteza anterioară [j] și cea posterioară $[w]$ leagă Romania balcanică (fără aromână) mai degrabă cu limbile slave decât cu italiana de sud, cu care coincide prin forma protezei anterioare, dar nu prin forma celei

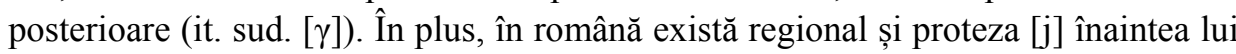
[a], caracteristică pentru slavă. Protezele centrale din română (de altfel, mult mai puțin consecvente) s-ar fi produs prin analogie cu celelalte proteze, adaptându-și locul de articulare. În slavă lipsesc astfel de proteze din cauza faptului că vocalele centrale se comportă acolo ca vocalele posterioare din care provin.

Până la urmă, peste tot a acționat același mecanism: întărirea iniţialei de silabă sau evitarea hiatului exterior prin introducerea protezelor și generalizarea ulterioară a acestora și la inițiala absolută, mai ales că slava veche și romanica balcanică nu aveau la finală decât silabe deschise care provocau hiaturi frecvente la limita cu următorul cuvânt. Trebuie remarcat însă că italiana care îndeplinea aceeași condiție nu cunoaşte fenomenul protezelor decât regional. Aici, se pare, mai intervine și un alt factor comun slavilor și romanicilor nord-balcanici: pronunția palatală a vocalelor anterioare și cea labială a vocalelor posterioare care ar fi degajat, la început de silabă, un apendice semiconsonantic foarte pronunțat. 
Aromâna nu urmează acest model, formând împreună cu neogreaca și periferia sudică a teritoriului slav (bulgara și macedoneana de sud) o arie aparte, fără proteze. Se pare că acolo a acționat influența limbii grecești care și-a impus fonotactica celorlalte limbi din zonă. În schimb, istroromâna coincide în privința protezelor cu dialectul croat local, iar meglenoromână - cu dialectele balcanoslave de nord, în mediul cărora s-a format înainte de stabilirea vorbitorilor ei în Meglen.

\section{BIBLIOGRAFIE}

Avram, A. (1964): Contribuţii la interpretarea grafiei chirilice a primelor texte românești. Studii şi Cercetări Lingvistice, XV: 1-5, 38-45.

Avram, M. (1990): Ortografie pentru toţi. Bucureşti: Editura Academiei Române.

BARTOLI, M. (2000): Il Dalmatico. Roma: Enciclopedia Italiana.

BorodinA, M. A. (1965): Morphologie historique du français. Москва, Ленинград: Просвещение.

CALOTĂ, I. (1986): Contribuţii la fonetica şi dialectologia limbii române. Craiova: Scrisul Românesc.

CANDREA, I.-A. (1916): Psaltirea Șcheiană în comparație cu celelalte Psaltiri din sec. XVI și XVII traduse din slavonește. București: Socec.

CAPIDAN, Th. (1925): Meglenoromânii. Istoria și graiul lor. Vol. I. București: Cultura Națională.

CAPIDAN, Th. (1932): Aromânii. Dialectul aromân. București: Imprimeria Naţională.

CARagiu-Marioțeanu, M. et al. (1977): Dialectologie română. București: Editura Didactică și Pedagogică.

CiORĂNESCU, Al. (2002): Dicționar etimologic al limbii române. București: Saeculum.

DAlametra, I. (1906): Dicționar macedo-român. București: Academia Română.

FRÂNCU, C. (2009): Gramatica limbii române vechi (1520-1780): Iași: Casa Editorială „Demiurg”.

Gramática de la llingua asturiana. (2001): Uviéu: Academia de la Llingua Asturiana.

IVĂNESCU, Gh. (1980): Istoria limbii române. Iași: Junimea.

Keleman, B. (1964): Cu privire la valoarea fonologică a literelor chirilice. Cercetări de Lingvistică, IX: 2, 183-186.

KovaČEC, A. (1971): Descrierea istroromânei actuale. București: Editura Academiei.

LAUSBERG, H. (1956): Romanische Sprachwissenschaft. Vol. I. Berlin: Walter de Gruyter.

MAŃCZAK, W. (1988): Języki romańskie. In: L. Bednarczuk (ed.): Języki indoeuropejskie. Vol. 2. Warszawa: Państwowe Wydawnictwo Naukowe, 571-644.

Martin, G., Moulin, B. (1998): Grammaire provençale et cartes linguistiques. Aix-enProvence: Edisud.

NANDRIȘ, O. (1963): Phonétique historique du roumain. Paris: C. Kilncksieck.

Papahagi, T. (1963): Dicționarul dialectului aromân. București: Editura Academiei Române.

Perlin, J. (2004): Metodologia językoznawstwa diachronicznego. Warszawa: Wydawnictwo Akademickie Dialog.

RĂDULESCU, M. (ed.). (1995): Îndreptar ortografic, ortoepic și de punctuație. București: Univers Enciclopedic.

RosetTI, Al. (1954): Influența limbilor slave meridionale asupra limbii române: sec. VI-XII. București: Editura Academiei RPR.

SALA, M. (1970): Contribuţii la fonetica istorică a limbii române. Bucureşti: Editura Academiei. 
SALA, M. (coord.) (1989): Enciclopedia limbilor romanice. București: Editura Știinţifică și Enciclopedică.

SALA, M. (coord.) (2001): Enciclopedia limbii române. București: Univers Enciclopedic.

SBIERA, I. G. (1885): Codicele Voronețean cu un vocabulariu și studiu asupra lui. Cernăuți: Tipografiea Archiepiscopală în Edificiile Reședinței.

SyPNICKI, J. (1977): Histoire interne et externe de la langue française. Poznań: Wydawnictwo Naukowe UAM.

VAsILIU, E. (1965): Fonologia limbii române. București: Editura Științifică.

VASILIU, E. (1968): Fonologia istorică a dialectelor dacoromâne. București: Editura Academiei. 